Journal of Applied Finance \& Banking, Vol. 10, No. 6, 2020, 203-223

ISSN: $1792-6580$ (print version), 1792-6599 (online)

https://doi.org/10.47260/jafb/10610

Scientific Press International Limited

\title{
The Effects of Exchange Rate Volatility on Exports in COMESA: A Panel Gravity Model Approach
}

\author{
Lucas Njoroge ${ }^{1}$
}

\begin{abstract}
In the recent past, exchange rate volatility has become a matter of concern for developing and emerging economies partly due to monetary policy actions of advanced economies and partly due to domestic policy actions. This study examines the effects of exchange rate volatility on exports, using a panel gravity model covering the period 1997 to 2019, to estimate pooled, fixed and random effects models for a panel of 19 COMESA member countries. Applying two alternative measures of exchange rate volatility, empirical results reveal that exchange rate volatility tends to depress both intra and extra-COMESA trade. The results suggest that policy makers in COMESA should not ignore exchange rate volatility when designing trade policies and strategies in member countries. Monetary authorities should strive to stabilize exchange rates by addressing the underlying causes of large, unpredictable and damaging exchange rate fluctuations while cautiously avoiding either further destabilizing the exchange rate or depleting foreign reserve buffers that could result in vulnerability to external shocks. It is also important to develop regional infrastructure like roads, railways and ports to further integrate the region and hence unlock the trade potential for COMESA region.
\end{abstract}

JEL classification numbers: F14, F30, F36.

Keywords: Exports, Intra Regional Trade, Exchange Rate Volatility, COMESA.

${ }^{1}$ Economist, COMESA Monetary Institute (CMI), Nairobi, Kenya.

Article Info: Received: August 10, 2020. Revised: September 2, 2020.

Published online: September 25, 2020. 


\section{Introduction}

Exchange rate volatility in the recent past is attracting a lot of attention in both academics and policy making circles. Policy actions of most developed countries are only making matters worse. It is evident that excessive exchange rate movements in emerging and developing economies, following the global financial and economic crisis, was largely attributed to economic stimulus packages in advanced economies and the US monetary policy normalization. Lately, interest rate policy actions in advanced economies have tended to trigger capital inflows/reversals to/from emerging and developing, causes excessive exchange rate movement in these economies. Going forward, the seemingly inward looking US trade policy under the current administration may lead to further exchange rate fluctuation for most developing countries' currencies including COMESA member countries. Coupled with lack or limited financial hedging instruments that impairs firm's ability to reduce risks arising from volatile currency movements, justify a relook on the important question of whether or not the volatility of exchange rate in the Common Market for Eastern and Southern Africa (COMESA) region affect exports.

As a region, COMESA strives to create a zone of monetary and financial stability to facilitate the integration of markets and the flow of trade. For this to be realized, exchange rate stability is critical in the region. However, most COMESA member States are under flexible exchange rate regimes aimed at allowing individual economies to pursue independent monetary policies in the face of external shocks. Monetary independence and accommodation of external shocks however remains elusive as flexible exchange rate regime have been associated with excessive exchange rate volatility. Also, the relationship between exchange rate volatility on trade has important implications on trade reforms. An adverse effect of exchange rate volatility on trade would mean that trade reforms must take this into account or risk being ineffective.

\section{Recent Trade Performance and Exchange Rate Volatility in COMESA}

Trade among COMESA member countries have been on an upward trend with the total intra-COMESA trade increasing from a low of USD 8.7 billion in 2005 to a high of USD 25.9 billion in 2013 before slowing down to 17.1 billion in 2016 and increasing to 22.1 billion in 2019. Exports and imports among COMESA member countries have remained fairly balance with a trade deficit of around USD 360 million and USD 367 Million in 2015 and 2019 respectively (Figure 1). 


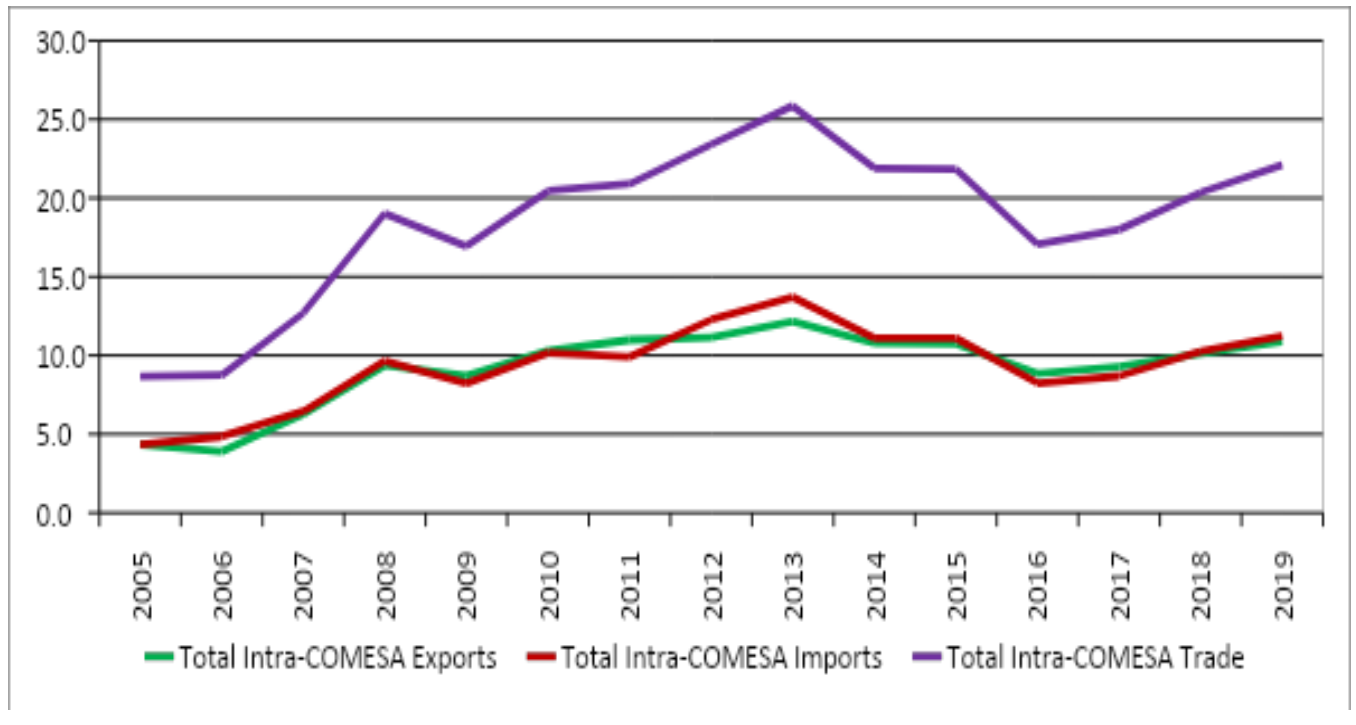

Figure 1: Intra COMESA Trade in USD Billions

Source: COMSTAT

However, at individual country level there is huge discrepancy in terms of shares that each COMESA member country commands in the region. Egypt, Kenya and Tunisia contributed 17.7 percent, 12.6 percent and 11.3 percent shares respectively, being the highest shares of total intra-COMESA trade in 2019. Egypt, Kenya and Zambia had the best export performance, exporting 26.3 percent, 14.7 Percent and 11.3 percent shares of total intra COMESA exports in 2019, respectively, while the main importers from the region were Tunisia, Libya and Kenya, with each importing 14.8 percent, 14.5 percent and 10.5 percent of the total intra-COMESA imports in 2019, respectively. Notable, countries with the highest positive net intraCOMESA export shares in 2019 were Egypt (17 percent surplus), Zambia (5.1 percent surplus) and Kenya (4.2 percent surplus). Countries with the highest intraCOMESA trade deficit shares (net importers) from the region in 2019 are Libya (12.2 percent share deficit), Tunisia (7 percent share deficit) and Somalia (4.5 percent share deficit), (Figure 2). 


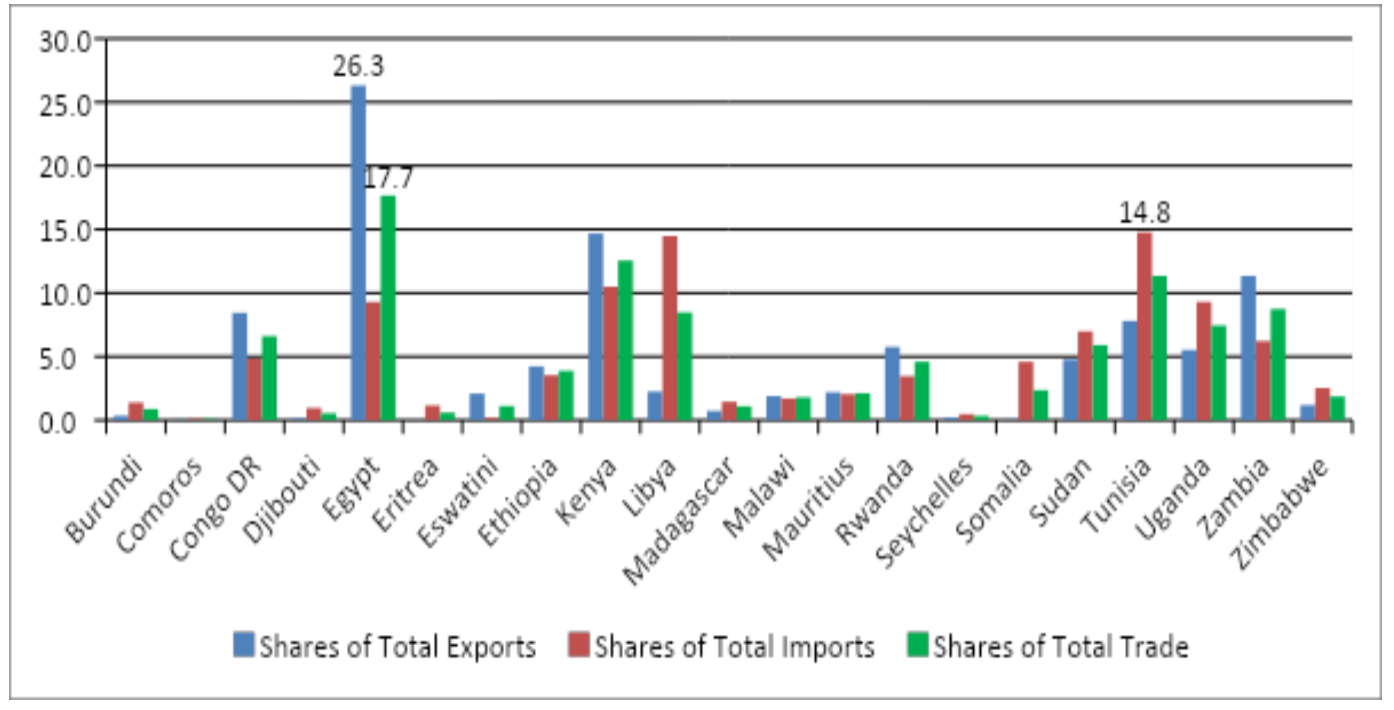

Figure 2: Intra - COMESA Trade Shares by Country in 2019

Source: COMSTAT

Extra-COMESA trade have also been in an upward trend rising from about USD 134.2 billion in 2005 to a peak of USD 318.8 billion in 2018 before slowing down to USD 302 billion in 2019. The region has been a net importer from the rest of the world with the deficit widening from USD 9.7 Billion in 2005 to a deficit of USD 111.8 billion in 2015, before narrowing slightly to a deficit of USD 99.5 billion in 2019. This may be a reflection of the nature of trade between the region and the rest of the world, with COMESA exporting low value commodities and importing high value industrial and manufactured goods from the rest of the world (Figure 3). 


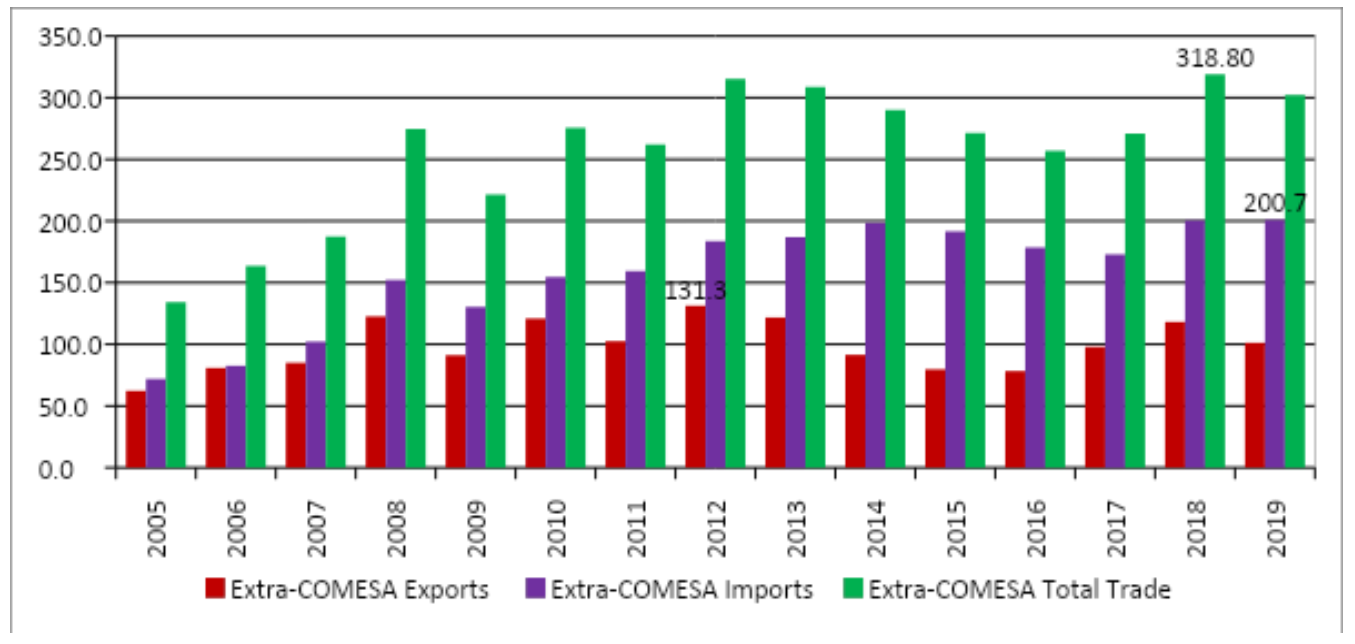

Figure 3: Extra COMESA Trade in USD Billions

Source: COMSTAT

COMESA share in world total trade remain fairly small increasing from 6 percent during the period 2005 - 2009, to 7 percent during the period 2010-2014 and 20152019, partly reflecting commodities price boom over this period. Over the same period, export shares to the world total exports increased from an average of 7 percent during the period 2005-2009, to 9 percent and 10 percent during the periods 2010-2014 and 2015-2019 respectively, while imports shares remained fairly constant at between 5 percent and 6 percent over the entire period under review (Figure 4).

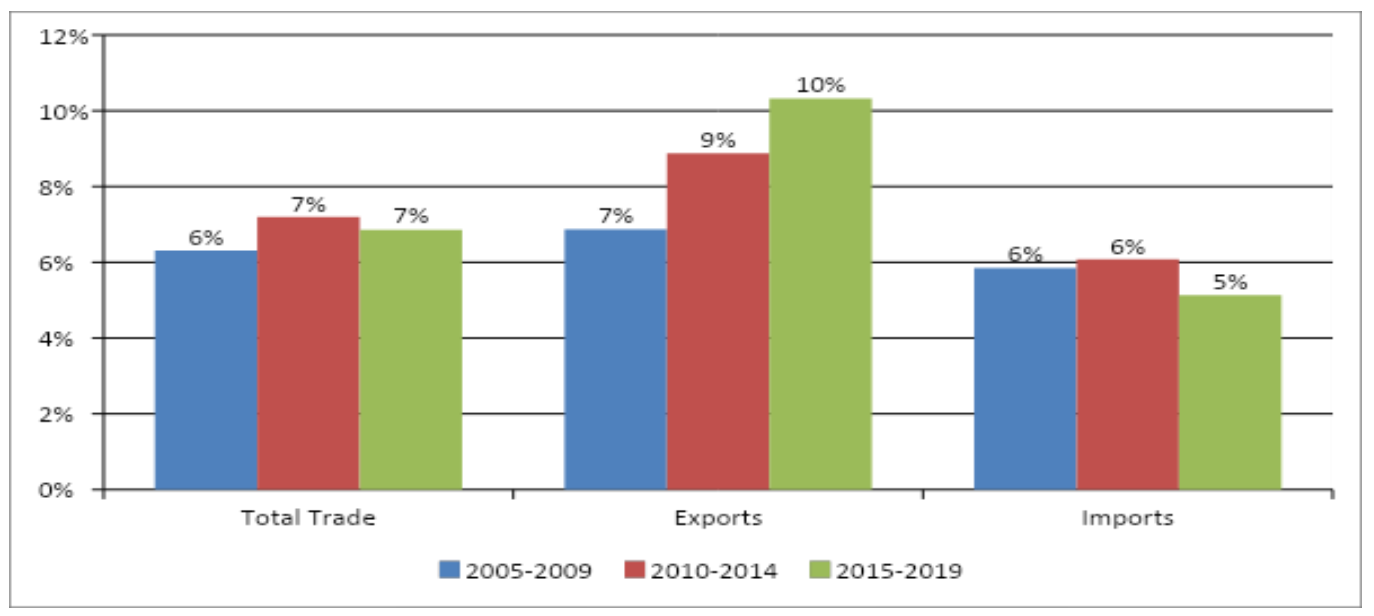

Figure 4: Comparison of Average Percentage Shares of Trade, Total Exports and Total Imports of COMESA to the World Shares

Source: COMSTAT 
The main exports markets for COMESA in 2019 were the EU (28 percent), COMESA (11 percent), UAE ( 9 percent), South Africa ( 8 percent), China ( 7 percent) and the Rest of the World (37 percent). In 2019, COMESA member countries exported goods worth USD 26.8 billion to the EU, USD 10.6 billion to COMESA, USD 8.1 billion to UAE, USD 7.8 billion to South Africa, USD 6.8 billion to China and USD 35.6 billion to the Rest of the World. The main exports were minerals products including petroleum oils, copper and cobalt (Figure 5).

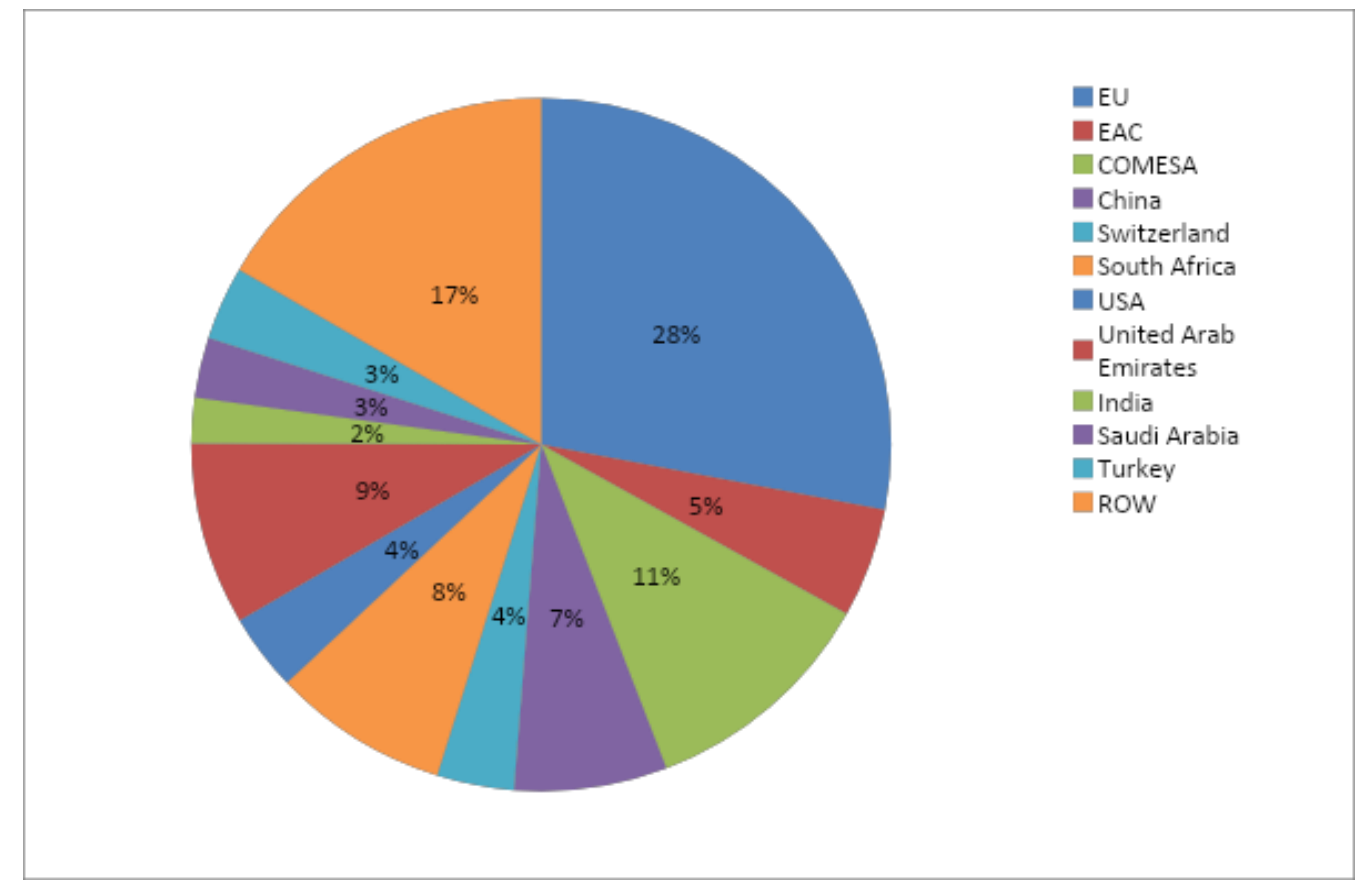

Figure 5: COMESA Key Export Market Shares, 2019

Source: COMSTAT

The main import markets for COMESA in 2019 are the EU, that exported goods worth about USD 47.1 billion ( 24 percent), China exports worth USD 30.3 billon (15 percent), USA exports worth 11.2 billion ( 6 percent), COMESA exports worth USD 10.9 billion (6 percent), with South Africa, United Arab Emirates, India and Saudi Arabia each exporting an equivalent of 5 percent share of total imports to the region, while the imports from the Rest of the World constituted about 30 percent of the total imports for goods in 2019. The main imports in 2019 by COMESA member countries were manufactures and fuels (Figure 6). 


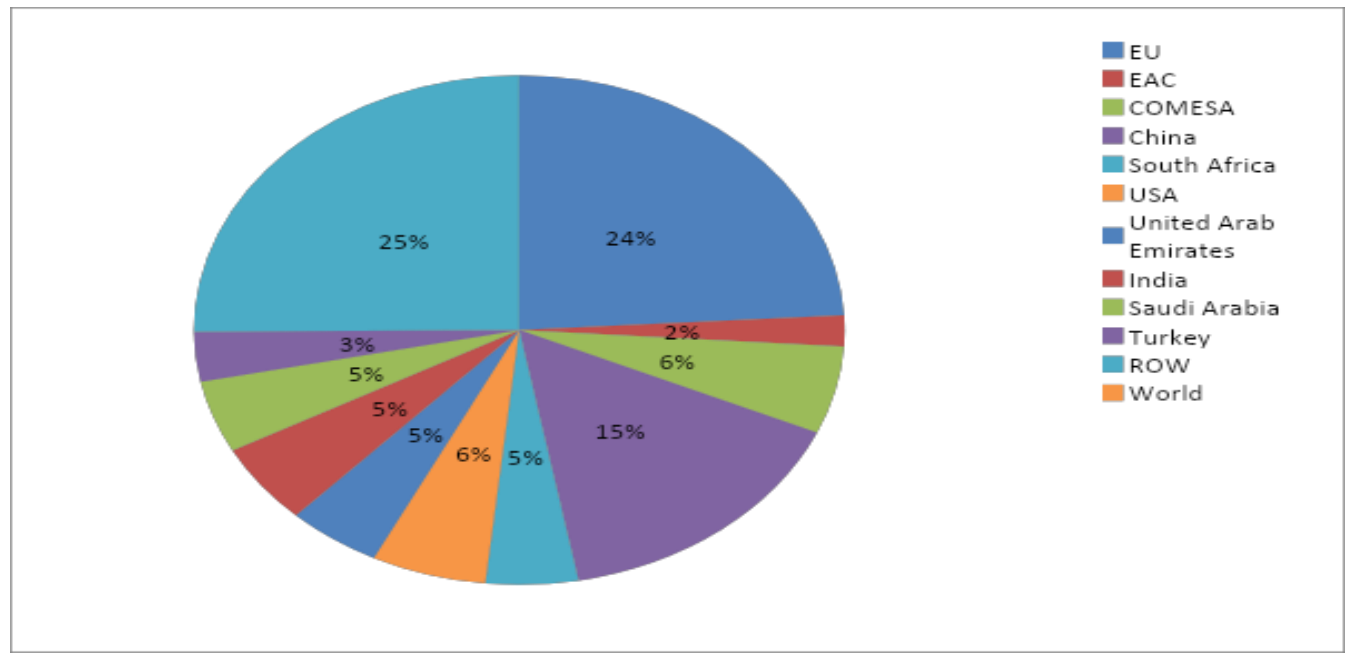

Figure 6: COMESA Key Import Market Shares, 2019

Source: COMSTAT

Using the real effective exchange rate index (REER) to visualize exchange rate volatility in COMESA, Figure 7 depicts the trend of REER for these countries in the region except DR Congo, Libya, Somalia and Tunisia. The figure shows that most currencies in the region have witnessed period of excessive volatility especially around 2001-2006 and 2015- 2019. DR Congo and Libya currencies tend to distort the picture as the two countries experienced hyperinflation during this period, Somalia does not have reliable data on REER while Tunisia only joined COMESA in 2018 (Figure 7).

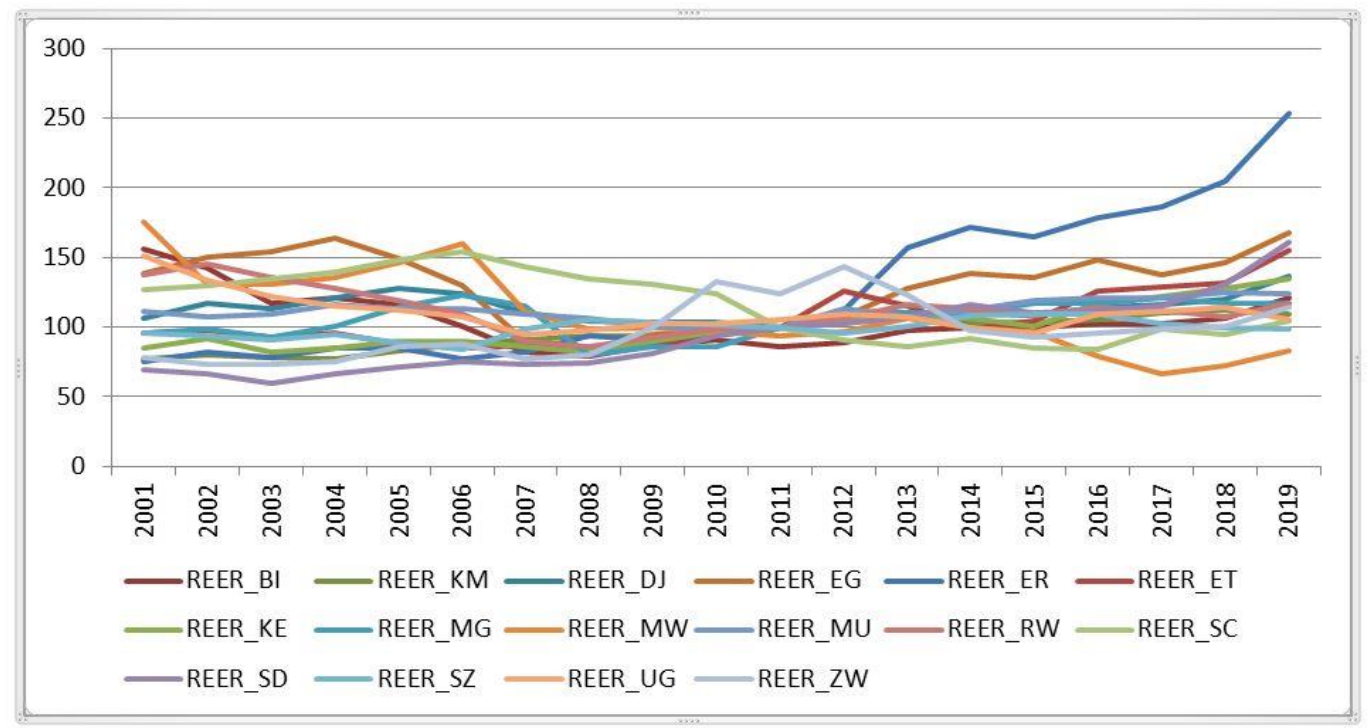

Figure 7: Real Effective Exchange Rate Index

Source: COMSTAT and IFS 
This study empirically investigates the link between exports and exchange rate volatility in the COMESA. The study is particularly important for COMESA region, as it extends our understanding of the effects of exchange rate volatility on exports and by extension helps in assessing whether such effects are necessarily disruptive or not, to the COMESA integration process. Studies for COMESA region have been few mainly due to lack of sufficient time series data. We use a unique data base from COMESA - COMSTAT database that have not been previously used for such an analysis, able to capture more precisely intra and extra-COMESA trade.

This paper makes a number of contributions that distinguishes it from the existing empirical literature. First, this is the first study to examine the impact of exchange rate volatility on exports for the entire COMESA region. Most countries in the region have been going through episodes of exchange rate volatility, whose implication on exports remains an empirical issue. Second, estimation with panel data controls for individual heterogeneity and nonstationarity, and can help improve efficiency of estimators by using data with more variability and less collinearity. Third, we use pooled, fixed and random effects models for panel data analysis which allow for serious robustness check of the empirical findings, unlike previous studies. Fourth, the paper applies alternative measures of exchange rate volatility that have recently gained traction in the empirical literature. Finally, the relationship between exchange rate volatility and exports is at best ambiguous and hence remains an empirical question with studies divided on whether the relationship is negative or positive, insignificant or significant.

\section{Literature Review}

Several studies both in developed and developing countries, neither theoretically nor empirically conclude whether stability of the exchange rate enhances exports or not (Clark et al., 2004). On the theoretical front, surveys by Cote (1994) and McKenzie (1999) provides a number of models supporting both negative and positive relationships between exchange rate volatility and exports. The theoretical argument in support of negative relationship between exchange rate volatility and exports is that when firms are risk averse, they tend to be willing to incur an additional cost to avoid exchange rate risk (especially if there is no futures or forward market for foreign exchange) so that the risk is not hedged, but is an implicit cost. This imply that the quantity of export supplied with this added cost is smaller with risk (similar effect on trade, as high transport costs) than without risk, the aggregate trade is hence reduced in the presence of exchange rate volatility. Hooper and Kohlhagen (1978) assuming no hedging possibilities, also reach the same conclusion of a clear negative relationship between exchange rate volatility and level of trade, arguing that firms reduce output and hence trade in response to exchange rate volatility in an effort to reduce their exposure to exchange rate risk. On the contrary, exchange rate volatility may increase exports if exporters have the knowledge and experience to predict exchange rate movement to their advantage. However, this depends on whether exchange rate movement is due to fundamentals 
or not. When exchange rate movement is as a result of the fundamentals, even the monetary authority's intervention to stabilize the exchange rate may be unsustainable, disruptive and harmful to trade. A negative relationship may be attributed to fundamentals when authorities are obliged to intervention through exchange rate controls or other restrictions on trade and payments. In such a case, exchange rate volatility creates incentives for trade protectionist tendencies and sharp currency reversals which in turn depress exports. In contrast, when firms hold a portfolio of several foreign currencies, it may diversify the exchange rate risk to its advantage, and instead of reducing, exchange rate volatility may increase exports depending on its reserve and currency mix. Makin (1978) showed that multinational corporation have many ways of hedging foreign exchange risks arising from trade by holding a basket of currencies to take advantage of some exchange rates moving in offsetting directions, providing a degree of protection to overall exposure to currency risk. Exchange rate volatility may also present not only a risk but an opportunity for reward. Increased exchange rate volatility present firms an excellent opportunity to increase prices not necessarily to compensate for the risk but to make extra profit. This is by being able to take advantage of profit opportunities when prices are relatively high, with expected profits being higher, the higher the exchange rate volatility, which motivates firms to increase exports (De Grauwe, 2005).

Another theoretical aspect of the relationship between exchange rate volatility and exports is the role of irreversible significant fixed investments (sunk costs) that firms engaged in exports incur. The sunk costs make firms less responsive to short run movements in exchange rate, opting to stay in the export market by adopting a wait and see approach as long as they can recover their variable costs. Dixit (1989) and Krugman (1989) explore the role of sunk costs as an option to enter or exit the export market, where the greater the volatility in exchange rates, the greater the value of keeping the option. This implies that increased exchange rate volatility, increases the inertia in entry and exit decisions.

On the empirical front, applying different estimation techniques such as instrumental variables estimations and introduction of fixed country effects, and using various volatility measures as well as sometimes decomposing it into anticipated and unanticipated volatility under GARCH framework, empirical studies do not also provide consistent results either (Clark et al. 2004 and Ozturk, 2006). Some studies find firm evidence that exchange rate volatility imposes significant negative effect on exports. Wei (1999) using a panel of 63 countries estimated switching regressions and finds a negative and statistically significant effect of exchange rate volatility on bilateral trade. Similarly, Rose (2000) estimates a gravity model with 186 countries and finds a negative and statistically significant relationship between exchange rate volatility and bilateral trade. Also, Rahman and Serletis (2006) examine the effects of exchange rate volatility on exports and output in the United States using a Structural Vector Autoregressive (SVAR) modified to accommodate multivariate GARCH. They find that exchange rate volatility has significant negative effects on exports. Similarly, Kihangire (2004) using 
disaggregated export data found that exchange rate variability has a negative impact on Uganda's exports.

In general, volatility in exchange rate affects exports negatively due to a number of reasons including increases in the level of trade riskiness that in turn creates uncertainty about the profits, causing the price of tradables to rise due to risk markup (risk premium) imposed by sellers in order to protect profits which adversely affects competitiveness of exports. In response to exchange rate volatility, firms shift resources from the risky tradable sector to the less risky non-tradable sector in order to protect their profits. Also, exchange rate volatility increases transaction costs as agents attempt to hedge against exchange rate risk (Schnabl, 2009 and Njoroge, L., 2015).

Ito et al. (2008) provide evidence that exchange rate volatility tends to discourage production networks for Japanese firms. They show that exchange rate stability is essential for back-and-forth transactions of intermediate goods in international production networks. Thorbecke (2008) finds that volatility does reduce trade in electronic parts and components exports within East Asia. Some studies do not find a negative and significant effect of exchange rate volatility on trade. Tenreyro (2004) using a gravity model with 104 countries finds insignificant effect of exchange rate volatility on trade. Other studies find mixed results. Cushman (1983) study on industrial countries found a negative and significant effect of volatility for six out of fourteen cases of bilateral trade flows. Similarly, IMF (1984) examined the impact of exchange rate volatility on bilateral exports between the G-7 countries and found only two cases with a negative and significant impact, while positive and significant impacts were identified for several cases.

Clark et al. 2004 applied a gravity model and various estimation techniques for a panel of 178 countries and concluded that, while there is evidence of a negative statistically significant impact of exchange rate volatility on trade, findings depends on the particular estimation technique employed. Arize et al. (2000) using Johansen's Multivariate procedure and Error Correction Model investigates both short and long term effect of exchange rate volatility on exports for 13 less developed counties. They find a significant negative effect of exchange rate volatility on exports for these countries for the period 1973 to 1996.

Consistent with these studies, IMF (2004) study finds exchange rate fluctuations increases during times of currency and balance of payments crises, and supports a negative relationship between exchange rate volatility and trade in some cases. However, the study show that such negative relationship is not robust to changes in model specification and if evident, the effect remains quantitatively small and not robust enough to allow a universal conclusion. The study concludes that, for the countries investigated, the effect of exchange rate volatility on trade is not of major policy concern but recommends the need for pursuing appropriate policies to avoid underlying causes of large, unpredictable and damaging exchange rate fluctuations. The above literature indicates that both theoretical and empirical findings do not provide consensus on the effect of exchange rate volatility on exports. Theoretical considerations fail to support the conventional assumption that the impact of 
exchange rate volatility on trade is negative, while empirical findings ranges from no impact to negative or positive impact. Empirical studies differ in empirical methodology, specification of the estimation equations, estimation techniques, sample used and therefore different findings. While there is no clear case that one model or estimation technique is superior to another, McKenzie, (1999) finds that most recent empirical studies based on panel data estimation techniques finds statistically significant relationship between exchange rate volatility and exports, attributed to more careful attention to the specification of the estimation technique and the measure of exchange rate volatility. This study follows much of the recent literature that uses panel data estimation techniques to examine such relationships for COMESA region (Ito et al., 2008 and Njoroge L., 2014).

\section{Methodology}

The theoretical justification of the gravity model for analyzing trade flows is well established in the literature (Bailey, Tavlas and Ulan 1987; Mckenzie, 1999; Tinbergen, 1962; Anderton and Skudelny, 2001). The starting point for gravity models is the adaptation of the law of universal gravitation to socioeconomic phenomena (Tinbergen, 1962 and Anderson, 1979) ${ }^{2}$. The gravity model assumes monopolistic competition, identical and homothetic preferences and relies on intraindustry trade as stipulated by technological gap and product-differentiation models. In its basic form, it models bilateral trade flows between countries as a positive function of the product of their incomes and a negative function of the geographical distance between them, such that trade flows (Xij) between two countries is expressed as:

$X_{i j}=k \frac{\left(Y_{i} \cdot Y_{j}\right)^{\alpha}}{D_{i j}^{\gamma}}$

Where $\mathrm{Yi}(\mathrm{j})$ is the economic size of the two trading partners respectively in terms of either Gross Domestic Product (GDP), population, endowment of labour, land or capital. Dij is the distance between the two countries (most commonly used is the distance between the capital cities of the two countries), $\mathrm{k}$ is a constant, while $\alpha, \beta$, and $\gamma$ are elasticity of $\mathrm{Xij}$ to change in $\mathrm{Yi}, \mathrm{Yj}$, and Dij. The model implies that high income countries trade more than low income countries, while more proximate countries trade more than distant countries.

By taking natural $\operatorname{logs}$ of equation 1 , and recalling that it is the combined economic size of the trading economies that determine their level of trade, we get the empirical linearized gravity model specification as:

\footnotetext{
2 The law of universal gravitations states that every point mass in the universe attracts every other point mass with a force that is directly proportional to the product of their masses and inversely proportional to the square of the distance between them.
} 
$\ln X_{i j}=k+\propto \ln \left(Y_{i} \cdot Y_{j}\right)-\gamma \ln D_{i j}$

This gravity equation postulates that trade between two countries increases in their economic size as captured by gross domestic product $\left(Y_{i} \cdot Y_{j}\right)$ and decreases in the cost of transportation between them as measured by the geographical distance between them.

There are other factors that affect exports between two countries and are related to the conceptual derivation of a gravity model hitching on either the attractiveness between two countries to trade or illustrating resistance to attractiveness to trade. We therefore generalize equation 2 above to take into account these other factors. These factors include geographical distance between two countries, adjacency, characteristic of geographical location (island, landlocked country), cultural similarity (common language, colonial links), membership to another trade organization, and more importantly for this study, the volatility of exchange rates. Taking into account these categories of variables, data limitation, time dimension, and that $\mathrm{Yi} . \mathrm{Yj}=\mathrm{Zij}=\mathrm{GDPij}$ represent the product of the GDP of the trading countries, our panel gravity model for estimation becomes:

$\ln X_{i j, t}=\propto_{1}+\propto_{2} \operatorname{lnGDP}_{i j, t}+\propto_{3}$ volatility $_{i j, t}+\propto_{4}$ Indistance $_{i j}+\propto_{5}$

In ln language l $_{j}+\alpha_{6}$ lnneighbours $_{i j}+\alpha_{7}$ Pop $_{i t}+P x_{i j, t}+\epsilon_{i j, t}$

Where $i j, t$ represents country $i$, country $j$ at time $t$; Xij,t represent exports of country $\mathrm{i}$ to country $\mathrm{j}$ at time $\mathrm{t}$, distance ij is the geographical distance between the capital cities of countries $i$ and $j$, language ij is a dummy variable taking the value of one if a common language is shared in both countries $i$ and $j$ and zero otherwise, neighboursij is a dummy variable that take the value of one if the two countries share a common border and zero otherwise, Pop it is the population of country $i$ at time t, $P x_{i j, t}$ is the relative price of exports between the two countries proxied by the Real Effective Exchange Rate (REER) and $\epsilon_{i j, t}$ an error term. Since data on relative price of exports is lacking for most of these countries, we proxy this variable with real effective exchange rate index for each country. All variables are in logs except the dummy variables and the measure of exchange rate volatility.

Just as in the theoretical and empirical literature on the relationship between exchange rate volatility and exports, there is still no consensus on the appropriate measure of volatility. Following the approach in much of the work on this topic (Ozturk, I. 2006., and Rahman, S. and Serletis, A. 2006), this study uses two different measures of exchange rate volatility, an observed volatility of exchange rate measured by the standard deviation of the nominal exchange rates, and conditional volatility based on a GARCH model. We use the nominal exchange rate instead of real exchange rate since we are interested in the short run analysis where costs of production are known and export and import prices have been determined. Besides, nominal and real exchange rate tend to move closely together given that domestic prices tend to be sticky, and therefore the choice of either may not 
significantly affect the measured volatility or the econometric results. A host of different indicators of volatility have been proposed in the recent literature (Clark et al., 2004, and Ozturk, 2006) and as such, rather than trying to argue for a single best measure, we use two alternative measures. While not an exhaustive list, these two measures of exchange rate volatility do summarize the intuition behind the broad types of methodologies that have been employed in coming up with most other measures.

First, the standard deviation (denoted as STDEV) is calculated from the end month real effective exchange rate indices over a one-year period to generate a series of annual figures used in the regression analysis.

Second, following similar studies on volatility such as Sirengar and Rajan (2004), the Real Effective Exchange Rate (ER) is modeled using the GARCH approach specified in equations 4 and 5:

$$
\Delta E R_{i, t}=\emptyset_{o}+\emptyset_{1} \Delta E R_{i, t-1}+\mu_{i, t}
$$

is the mean equation,

and where $\mu_{i, t}=v_{i, t}\left(\alpha_{o}+\alpha_{1} \mu_{i, t-1}^{2}+\tau h_{i, t-1}\right)^{0.5}$ and,

$h_{i, t}=\propto_{o}+\alpha_{1} \mu_{i, t-1}^{2}+\tau h_{i, t-1}$

is the variance equation.

Where exchange rate is expressed in logs, $\left|\emptyset_{i}\right|<1, v_{i, t} \sim$ i.i.d $(0,1), \Delta$ is the difference operator, $\alpha \mathrm{o}$ and $\alpha 1$ are constants and strictly positive and $\mu_{i, t}$ is an error term. In the conditional variance equation (5), $\alpha$ is the mean term, $\mu_{i, t-1}^{2}$ is the $\mathrm{ARCH}$ term representing news about volatility from the previous period, and $h_{i, t-1}$ is the GARCH term representing the last period's forecast error variance. In the estimation, a GARCH $(1,1)$ was found to be parsimonious and hence used to generate conditional volatility of the exchange rate.

It is important to note that the GARCH $(1,1)$ model in equation 4 and 5 imply that there is no relationship between real effective exchange rate (REER) and its error term. This allows the estimation of equation 3 together with Px term and the conditional variance term from equation 5 and still be devoid of various econometric challenges of such inclusion. However, the same cannot be done with the alternative volatility measure, the standard deviation.

We also run the model with extra-COMESA exports to check whether exchange rate volatility is an important determinant for trade with the rest of the world. The study focuses on exports and not overall trade because imports to the region are generally inputs in the production process or are manufactured goods, both characterized by inelastic demand and hence tends to respond less to exchange rate fluctuations. 


\subsection{Data and the Estimation Technique}

We use COMESA COMSTAT database for intra and Extra - COMESA trade including Exports data for each country. For most of the other variables we use World Development Indicators (WDI) and IMF's International Financial Statistics (IFS) data (See Appendix Table A1 for the completed list of variables and data sources). The study uses pooled, fixed and random effects estimation techniques for a panel of 19 COMESA member countries. Somalia did not have a completed data over the period for all the years, while Tunisia was dropped because it only joined COMESA in 2018.

We restrict the analysis to intra and extra-COMESA exports in order to examine more closely the impact of exchange rate volatility on exports for a region whose overriding mandate is to promote trade and investment.

\section{Results}

The results of empirical analysis are reported in Table 1 and Table 2. Table 1 report results when the dependent variable is intra-COMESA exports while Table 2 are results when the dependent variable is Extra-COMESA exports. For robustness check, three sets of empirical results are reported, the pooled, the fixed effects and the random effects models results. In all cases, the models diagnostics show reasonable R-squared and Adjusted R-squared, especially in a panel data context. In each model, we distinguish four equations based on two different measures of exchange rate volatility (condition variance and standard deviation) and two dummies, one for sharing a border (NBR) and the other for sharing an official language (LG). The common variables in the three sets of equations are the constant, Gross domestic product (GDP), Population (pop), Distance (Dis) and price of exports (Pex).

Table 1 results indicate that GDP, population and price of exports each has a positive and significantly effect on intra-COMESA exports. The distance variable (DIS) on the other hand shows a negative and significant effect on intra-COMESA exports only when the coefficient on the dummy variable for sharing an official language (LG) is significant. Sharing an official language tend to promote exports for countries in COMESA, implying that language barrier tend to deter trade in the region. This could imply that when countries share an official language, exports between them increases but proportionately decrease as the distance increases. However, distance is not an important deterrent to exports when countries share a border possibly signifying the ever increasing cross-border trade between neighbours in COMESA and by extension the improvement in intra-COMESA exports.

On the variable of interest to this study, exchange rate volatility using both measures (conditional variance and standard deviation) negatively and significantly affects intra-COMESA exports in all the three sets of models (Table 1). This implies that exchange rate volatility adversely affects exports within COMESA possibly reflecting the over-reliance on the US Dollar for trade within the region. 
Similarly, the results on extra-COMESA trade in Table 2 show that GDP, population and price of exports each has a positive and significantly affect ExtraCOMESA exports. The distance variable (DIS) negatively and significantly affects extra-COMESA exports only when the coefficient on the dummy variable for sharing an official language (LG) is significant. This implies that for extraCOMESA Trade, distance matters in influencing exports, where the greater the distance, the less the exports. Sharing official language enhances exports between countries of the region and the rest of the world.

Consistent with the results of intra-COMESA trade, exchange rate volatility (using the two measures, the conditional variance and the standard deviation) negatively and significantly affects extra-COMESA exports in all the three sets of models.

This implies that exchange rate volatility adversely affects exports with none COMESA member countries.

The main difference between the results in Table 1 and Table 2 is that the dummy variable for sharing a border (NBR) becomes insignificant when in the same equation with the variable for distance (DIS). This could mean that for extraCOMESA exports, distance is a more significant deterrent to exports, possibly due to the associated increase in transportation costs. Interpreted together with the equations that uses the sharing of language dummy (LG), that drops the NBR dummy $^{3}$, the distance variable (DIS) become negatively significant in influencing extra-COMESA trade. That is, distance adversely affects extra-COMESA exports, while sharing an official language facilitates trade. For neighboring countries, distance does not matter much in deterring extra-COMESA exports.

3 Partly to avoid the dummy variable trap but also to examine the role of sharing an official language in promoting trade. 
Table 1: Regression of Total Exports for Country i with COMESA Countries (EXC)

\begin{tabular}{|c|c|c|c|c|c|c|c|c|c|c|c|c|}
\hline Variable & \multicolumn{4}{|c|}{ Pooled Model } & \multicolumn{4}{|c|}{ Fixed Effects Model } & \multicolumn{4}{|c|}{ Radom Effects Model } \\
\hline Equation & (1) & (2) & (3) & (4) & (5) & (6) & (7) & (8) & (9) & (10) & (11) & (12) \\
\hline Constant & $\begin{array}{l}4.39 * \\
(0.65) \\
\end{array}$ & $\begin{array}{l}4.68 * \\
(0.70)\end{array}$ & $\begin{array}{c}4.65 * * \\
(0.70) \\
\end{array}$ & $\begin{array}{l}4.42 * \\
(0.66) \\
\end{array}$ & $\begin{array}{l}6.63 * \\
(1.38) \\
\end{array}$ & $\begin{array}{l}6.24 * \\
(1.37) \\
\end{array}$ & $\begin{array}{l}6.33 * \\
(1.38) \\
\end{array}$ & $\begin{array}{l}6.67 * \\
(1.38) \\
\end{array}$ & $\begin{array}{c}21.07 * \\
(3.11) \\
\end{array}$ & $\begin{array}{l}17.65^{*} \\
(2.89) \\
\end{array}$ & $\begin{array}{l}21.31 * \\
(3.18) \\
\end{array}$ & $\begin{array}{l}18.76^{*} \\
(3.043) \\
\end{array}$ \\
\hline LOG (GDP) & $\begin{array}{l}0.73 * \\
(0.06)\end{array}$ & $\begin{array}{l}0.74 * \\
(0.06)\end{array}$ & $\begin{array}{l}0.71 * \\
(0.06)\end{array}$ & $\begin{array}{c}0.7^{*} \\
(0.06)\end{array}$ & $\begin{array}{l}0.83 * \\
(0.32)\end{array}$ & $\begin{array}{c}0.74 * * \\
(0.33)\end{array}$ & $\begin{array}{l}0.71 * * \\
(0.33)\end{array}$ & $\begin{array}{c}0.81 * * \\
(0.32)\end{array}$ & $\begin{array}{c}0.4^{*} \\
(0.11)\end{array}$ & $\begin{array}{c}0.4^{*} \\
(0.11)\end{array}$ & $\begin{array}{c}0.4^{*} \\
(0.09)\end{array}$ & $\begin{array}{l}0.4^{*} \\
(0.1)\end{array}$ \\
\hline LOG (POP) & $\begin{array}{c}0.16 * * \\
(0.07)\end{array}$ & $\begin{array}{c}0.15 * * * \\
(0.08)\end{array}$ & $\begin{array}{c}0.14 * * * \\
(0.08)\end{array}$ & $\begin{array}{c}0.15 * * \\
(0.07)\end{array}$ & $\begin{array}{l}0.7^{*} \\
(0.2)\end{array}$ & $\begin{array}{l}0.74 * \\
(0.21)\end{array}$ & $\begin{array}{l}0.069 * \\
(0.04)\end{array}$ & $\begin{array}{c}0.24 * * * \\
(0.14)\end{array}$ & $\begin{array}{l}0.94 * \\
(0.09)\end{array}$ & $\begin{array}{l}0.93 * \\
(0.09)\end{array}$ & $\begin{array}{l}0.98 * \\
(0.09)\end{array}$ & $\begin{array}{l}0.98 * \\
(0.09)\end{array}$ \\
\hline LOG (DIS) & $\begin{array}{l}-0.03^{+} \\
(0.05)\end{array}$ & $\begin{array}{c}-0.04 * * * \\
(0.02)\end{array}$ & $\begin{array}{c}-0.03+ \\
(0.06)\end{array}$ & $\begin{array}{c}-0.04 * * * \\
(0.02)\end{array}$ & $\begin{array}{c}-0.049^{+} \\
(0.04)\end{array}$ & $\begin{array}{c}-0.08 * * \\
(0.04)\end{array}$ & $\begin{array}{c}-0.079^{+} \\
(0.2)\end{array}$ & $\begin{array}{c}-0.048 * * * \\
(0.03)\end{array}$ & $\begin{array}{c}-0.15^{+} \\
(0.19) 1\end{array}$ & $\begin{array}{c}-0.045^{* *} \\
(0.03)\end{array}$ & $\begin{array}{c}-0.032^{+} \\
(0.58)\end{array}$ & $\begin{array}{c}-0.06 * * \\
(0.03)\end{array}$ \\
\hline $\mathrm{Px}$ & $\begin{array}{c}0.28 * * * \\
(0.03)\end{array}$ & $\begin{array}{c}0.45 * * * \\
(0.03)\end{array}$ & & & $\begin{array}{c}0.26 * * * \\
(0.03)\end{array}$ & $\begin{array}{c}0.36^{* * * *} \\
(0.10)\end{array}$ & & & $\begin{array}{c}0.36 * * * \\
(0.11)\end{array}$ & $\begin{array}{c}0.38 * * * \\
(0.12)\end{array}$ & & \\
\hline \multicolumn{13}{|c|}{ Volatility Measures } \\
\hline $\mathrm{CV}$ & $\begin{array}{c}-0.73^{*} \\
(0.06)\end{array}$ & $\begin{array}{l}-0.74^{*} \\
(0.06)\end{array}$ & $\begin{array}{c}0.28 * * * \\
(0.02)\end{array}$ & $\begin{array}{c}0.44 * * * \\
(0.03)\end{array}$ & $\begin{array}{l}-0.53^{*} \\
(0.07)\end{array}$ & $\begin{array}{l}-0.56^{*} \\
(0.07)\end{array}$ & $\begin{array}{c}0.28 * * * \\
(0.02)\end{array}$ & $\begin{array}{c}0.43 * * * \\
(0.03)\end{array}$ & $\begin{array}{l}-0.57^{*} \\
(0.07)\end{array}$ & $\begin{array}{l}-0.56^{*} \\
(0.07)\end{array}$ & $\begin{array}{c}0.45 * * * \\
(0.03)\end{array}$ & $\begin{array}{c}0.26^{* * *} \\
(0.03)\end{array}$ \\
\hline $\begin{array}{c}\text { LOG } \\
(\mathrm{STDEV})\end{array}$ & & & $\begin{array}{l}-0.31^{*} \\
(0.05)\end{array}$ & $\begin{array}{l}-0.33 * \\
(0.05)\end{array}$ & & & $\begin{array}{l}-0.32 * \\
(0.05)\end{array}$ & $\begin{array}{c}-0.38^{* *} \\
(0.22)\end{array}$ & & & $\begin{array}{c}-0.36 * * \\
(0.21)\end{array}$ & $\begin{array}{c}-0.37 * * \\
(0.22)\end{array}$ \\
\hline \multicolumn{13}{|c|}{ Dummy Variables } \\
\hline LG & & $\begin{array}{c}0.34 * * * \\
(0.11)\end{array}$ & & $\begin{array}{c}0.33 * * * \\
(0.10)\end{array}$ & & $\begin{array}{c}0.24 * * \\
(0.11)\end{array}$ & & $\begin{array}{c}0.25 * * * \\
(0.05)\end{array}$ & & $\begin{array}{c}0.75 * * * \\
(0.25)\end{array}$ & & $\begin{array}{c}0.79 * * * \\
(0.26)\end{array}$ \\
\hline NBR & $\begin{array}{l}0.14 * \\
(0.08)\end{array}$ & & $\begin{array}{c}0.08 * * \\
(0.04)\end{array}$ & & $\begin{array}{l}0.07 * \\
(0.04)\end{array}$ & & $\begin{array}{c}0.32 * * * \\
(0.05)\end{array}$ & & $\begin{array}{l}0.16^{+} \\
(0.19)\end{array}$ & & $\begin{array}{c}0.37^{+} \\
(0.70)\end{array}$ & \\
\hline \multicolumn{13}{|c|}{ Model Diagnostics } \\
\hline R-Squared & 0.558 & 0.561 & 0.566 & 0.552 & 0.844 & 0.847 & 0.847 & 0.844 & 0.632 & 0.761 & 0.741 & 0.722 \\
\hline $\begin{array}{c}\text { Adjusted } \\
\text { R-Squared }\end{array}$ & 0.546 & 0.553 & 0.551 & 0.545 & 0.828 & 0.835 & 0.835 & 0.828 & 0.626 & 0.756 & 0.737 & 0.717 \\
\hline
\end{tabular}


Table 2: Regression of Total Exports of Country i with Non COMESA Countries (EXW)

\begin{tabular}{|c|c|c|c|c|c|c|c|c|c|c|c|c|}
\hline Variable & \multicolumn{4}{|c|}{ Pooled Model } & \multicolumn{4}{|c|}{ Fixed Effects Model } & \multicolumn{4}{|c|}{ Radom Effects Model } \\
\hline Equation & (1) & $(2)$ & (3) & (4) & (5) & (6) & (7) & (8) & (9) & (10) & (11) & (12) \\
\hline Constant & $\begin{array}{l}5.00 * \\
(0.71)\end{array}$ & $\begin{array}{l}4.88 * \\
(0.74)\end{array}$ & $\begin{array}{l}4.87 * \\
(0.74)\end{array}$ & $\begin{array}{l}4.98 * \\
(0.71)\end{array}$ & $\begin{array}{c}7.53 * \\
(1.23)\end{array}$ & $\begin{array}{c}7.09 * * \\
(1.18)\end{array}$ & $\begin{array}{l}6.93 * \\
(1.18)\end{array}$ & $\begin{array}{l}6.74 * \\
(1.20)\end{array}$ & $\begin{array}{c}16.40 * \\
(2.68)\end{array}$ & $\begin{array}{c}14.97 * \\
(2.57)\end{array}$ & $\begin{array}{c}11.95 * \\
(2.10)\end{array}$ & $\begin{array}{l}12.86^{*} \\
(2.21)\end{array}$ \\
\hline LOG(GDP) & $\begin{array}{l}0.21 * \\
(0.05)\end{array}$ & $\begin{array}{l}0.48 * \\
(0.24)\end{array}$ & $\begin{array}{c}0.28 * * * \\
(0.14)\end{array}$ & $\begin{array}{l}0.53 * \\
(0.26)\end{array}$ & $\begin{array}{l}0.74 * \\
(0.25)\end{array}$ & $\begin{array}{c}0.52 * * \\
(0.24)\end{array}$ & $\begin{array}{l}0.32 * \\
(0.10)\end{array}$ & $\begin{array}{l}0.32 * \\
(0.12)\end{array}$ & $\begin{array}{l}077^{*} \\
(0.25)\end{array}$ & $\begin{array}{l}0.49 * \\
(0.26)\end{array}$ & $\begin{array}{l}0.75^{*} \\
(0.25)\end{array}$ & $\begin{array}{l}0.79 * \\
(0.26)\end{array}$ \\
\hline LOG(POP) & $\begin{array}{l}0.45^{*} \\
(0.07)\end{array}$ & $\begin{array}{c}0.47 * \\
(0.066)\end{array}$ & $\begin{array}{l}0.48^{*} \\
(0.07)\end{array}$ & $\begin{array}{l}0.47 * \\
(0.07)\end{array}$ & $\begin{array}{l}0.50 * \\
(0.16)\end{array}$ & $\begin{array}{l}0.52 * \\
(0.16)\end{array}$ & $\begin{array}{l}0.52 * \\
(0.12)\end{array}$ & $\begin{array}{l}0.53 * \\
(0.13)\end{array}$ & $\begin{array}{l}0.87 * \\
(0.27)\end{array}$ & $\begin{array}{l}0.91 * \\
(0.27)\end{array}$ & $\begin{array}{l}0.98 * \\
(0.34)\end{array}$ & $\begin{array}{c}0.08 * * \\
(0.04)\end{array}$ \\
\hline LOG(DIS) & $\begin{array}{c}-0.054^{+} \\
(0.04) \\
\end{array}$ & $\begin{array}{c}-0.24 * \\
(0.11)\end{array}$ & $\begin{array}{c}-0.009^{+} \\
(0.05)\end{array}$ & $\begin{array}{l}-0.06 * \\
(0.04) \\
\end{array}$ & $\begin{array}{l}-0.03^{+} \\
(0.58) \\
\end{array}$ & $\begin{array}{c}-0.07 * * \\
(0.03)\end{array}$ & $\begin{array}{c}-0.093^{+} \\
(0.20) \\
\end{array}$ & $\begin{array}{c}-0.08 * * * \\
(0.04)\end{array}$ & $\begin{array}{c}0.01+ \\
(0.02)\end{array}$ & $\begin{array}{c}-0.06 * * \\
(0.03)\end{array}$ & $\begin{array}{l}-0.04^{+} \\
(0.04)\end{array}$ & $\begin{array}{c}-0.06 * * \\
(0.03)\end{array}$ \\
\hline Px & $\begin{array}{c}0.18 * \\
(0.1)\end{array}$ & $\begin{array}{c}0.32 * * * \\
(0.11)\end{array}$ & & & $\begin{array}{c}0.19 * \\
(0.1)\end{array}$ & $\begin{array}{l}0.14^{*} \\
(0.08)\end{array}$ & & & $\begin{array}{c}0.21 * * \\
(0.09)\end{array}$ & $\begin{array}{c}0.17 * * \\
(0.08)\end{array}$ & & \\
\hline \multicolumn{13}{|c|}{ Volatility Measures } \\
\hline $\mathrm{CV}$ & $\begin{array}{c}-0.71 * \\
(0.06)\end{array}$ & $\begin{array}{c}-0.70 * \\
(0.06)\end{array}$ & $\begin{array}{c}0.53 * * * \\
(0.03)\end{array}$ & $\begin{array}{c}0.56 * * * \\
(0.03)\end{array}$ & $\begin{array}{l}-0.24 * \\
(0.05)\end{array}$ & $\begin{array}{c}-0.23 * \\
(0.05) \\
\end{array}$ & $\begin{array}{c}0.30 * * * \\
(0.11)\end{array}$ & $\begin{array}{c}0.53 * * * \\
(0.03)\end{array}$ & $\begin{array}{c}-0.24 * \\
(0.05)\end{array}$ & $\begin{array}{c}-0.25 * \\
(0.05)\end{array}$ & $\begin{array}{l}0.19 * \\
(0.11) \\
\end{array}$ & $\begin{array}{l}0.2 * * \\
(0.09)\end{array}$ \\
\hline LOG(STDEV) & & & $\begin{array}{c}-0.06 * * \\
(0.023)\end{array}$ & $\begin{array}{c}-0.05 * * \\
(0.02)\end{array}$ & & & $\begin{array}{c}-0.04 * * * \\
(0.02)\end{array}$ & $\begin{array}{c}-0.19 * \\
(0.06)\end{array}$ & & & $\begin{array}{c}-0.17 * \\
(0.06)\end{array}$ & $\begin{array}{c}-0.19 * \\
(0.06)\end{array}$ \\
\hline \multicolumn{13}{|c|}{ Dummy Variables } \\
\hline LG & & $\begin{array}{l}0.92 * \\
(0.27) \\
\end{array}$ & & $\begin{array}{l}0.87 * \\
(0.87) \\
\end{array}$ & & $\begin{array}{c}0.98 * * * \\
(0.09)\end{array}$ & & $\begin{array}{c}0.71 * * \\
(0.33)\end{array}$ & & $\begin{array}{c}0.06^{* * *} \\
(0.03)\end{array}$ & & $\begin{array}{c}0.07 * * * \\
(0.19)\end{array}$ \\
\hline NBR & $\begin{array}{l}0.06+ \\
(0.05)\end{array}$ & & $\begin{array}{l}0.86+ \\
(0.55)\end{array}$ & & $\begin{array}{c}0.10^{+} \\
(0.15) 9\end{array}$ & & $\begin{array}{l}0.17^{+} \\
(0.14)\end{array}$ & & $\begin{array}{c}0.28^{+} \\
(0.28)\end{array}$ & & $\begin{array}{l}0.23^{+} \\
(0.16)\end{array}$ & \\
\hline \multicolumn{13}{|c|}{ Model Diagnostics } \\
\hline R-Squared & 0.623 & 0.648 & 0.62 & 0.650 & 0.804 & 0.817 & 0.802 & 0.817 & 0.595 & 0.623 & 0.598 & 0.627 \\
\hline $\begin{array}{c}\text { Adjusted } \\
\text { R- Squared }\end{array}$ & 0.618 & 0.642 & 0.614 & 0.645 & 0.790 & 0.803 & 0.788 & 0.803 & 0.589 & 0.619 & 0.592 & 0.622 \\
\hline
\end{tabular}




\section{Conclusion and Policy Implications}

This study set to empirically investigate the relationship between exchange rate volatility and exports in COMESA. Congruent with similar studies (Ozturk, I. 2006 and Rahman, S. and Serletis, A. 2006), exports in COMESA positively and significantly depend on GDP, population and price of exports, implying that the bigger the economy of the trading partner and the higher the exports prices, the higher the trade between countries. Sharing an official language also has a positive and significant effect on exports, implying that sharing an official language tends to promote exports, and hence language barriers tend to deter trade in the region. Distance is not an important deterrent to exports when countries share a border possibly signifying the ever increasing cross-border trade between neighbours in COMESA and by extension the ever increasing intra-COMESA exports. The empirical results also reveal that exchange rate volatility tend to depress both intra and extra-COMESA trade. Intra COMESA trade is discouraged by exchange rate volatility more seriously than geographical distance and related transport costs between countries.

The results suggest that policy makers in COMESA should not ignore exchange rate volatility when designing export promotion policies and strategies in member countries. Exchange rate volatility should form an essential part of trade and exchange rate policy formulation and implementation and hence require monetary authorities in the region to strive to stabilize exchange rates. However, exchange rate stabilization strategy should be carefully thought out to avoid either further destabilizing the exchange rate or depleting foreign reserve buffers that could result in vulnerability to external shocks. Measures to influence exchange rate expectations and anchor inflation will be highly desirable. Critically important is the need to pursue appropriate policies to avoid underlying causes of large, unpredictable and damaging exchange rate fluctuations. It is also important to develop regional infrastructure like roads, railways and ports to further integrate the region and hence unlock the trade potential for COMESA region. 


\section{References}

[1] Anderson J.E., (1979). A Theoretical Foundation for the Gravity Equation. American Economic Review, 69 (1), pp. 106-116.

[2] Anderton, R., and Skudelny, F. (2001). Exchange rate volatility and Euro Area imports. ECB Working Paper No. 64, Frankfurt am Main, Germany: European Central Bank.

[3] Arize, A.C., Osang, T. and Stottje, D.J. (2000). Exchange Rate Volatility and Foreign Trade: Evidence from thirteen LDCs. Journal of Business and Economic Statistics, 18 (1), pp. 10-17.

[4] Bailey, M.J., Tavlas, G.S., and Ulan, M. (1987). The impact of exchange rate volatility on export growth: some theoretical considerations and empirical results. Journal of Policy Modeling 9, pp. $225-243$.

[5] Clark, P., Tamirisa, N., Wei, S., Sadikov, A., and Zeng, L., (2004). A new look at exchange rate volatility and trade flows. International Monetary Fund, Washington DC, Occasional Paper, No. 235.

[6] Côté, Agathe., (1994). Exchange Rate Volatility and Trade. Working Paper No. 94-5, Bank of Canada.

[7] Cushman, D.O. (1983). The effects of real exchange rate risk on international trade. Journal of International Economics, 15(1-2), pp 45-63.

[8] De Grauwe P., (2005). The Economics of Monetary Union. Sixth Revised Edition. Oxford University Press.

[9] Dixit, A. (1989). Entry and exit decisions under uncertainty. Journal of Political Economy, 97(3), pp. 620-638.

[10] Hooper, Peter, and Steven Kohlhagen, (1978). The Effect of Exchange Rate Uncertainty on the Prices and Volume of International Trade. Journal of International Economics, 8 pp. 483-511.

[11] Ito, T., Koibuchi, S., Sasaki, Y., Sato, K., Shimizu, J., Hayakawa, K., Yoshimi, T. (2008). Choice of invoice currency and exchange risk management: Case studies of Japanese firms. RIETI Discussion Paper Series J-009

[12] International Monetary Fund (IMF). (1984). Exchange rate volatility and world trade. IMF occasional paper No. 28, Washington DC: IMF.

[13] International Monetary Fund (IMF). (2004). Exchange rate volatility and trade flows - some new evidence. IMF Policy Papers, Washington DC: IMF.

[14] Kihangire, D. (2004). The Effects of Exchange Rate Variability of Exports: Evidence from Uganda, 1988-2001. Economic and Social Research Council (ESRC), Oxford, February 2004.

[15] Krugman, P. (1989). Exchange rate instability. Massachusetts Institute of Technology.

[16] Makin, John H. (1978). Portfolio Theory and the Problem of Foreign Exchange Risk. Journal of Finance 33, pp. 517-34.

[17] McKenzie, M. (1999). The Impact of exchange rate volatility on international trade flows". Journal of Economic Surveys 13(1), pp. 71-106.

[18] Njoroge, L.K. (2015). The Financial Trilemma and Macroeconomic Instability: 
Empirical Evidence from Kenya. American Journal of Trade and Policy, 2 (1) pp. 59-70.

[19] Njoroge, L.K., and Shem O. (2014). Determinants of Banks Expansion in the East African Community: An Empirical Analysis of Kenyan Banks. Kenya Bankers Association WPS 04/14

[20] Njoroge, L.K. (2010). The impact of regional integration on economic growth: empirical evidence from COMESA, EAC and SADC trade blocs. American Journal of Social and Management Sciences, 1(2) pp. 30-45

[21] Ozturk, I. (2006). Exchange Rate Volatility and Trade: A Literature Survey. International Journal of Applied Econometrics and Quantitative Studies, 3(1): pp. 85-102.

[22] Rahman, S. and Serletis, A. (2006). The Effects of Exchange Rate Uncertainty: Evidence from a Multivariate GARCH-in-Mean VAR. University of Calgary, Calgary, Alberta, T2N 1N4, Canada.

[23] Rose, A. K. (2000). One money, one market: The effect of common currencies on trade" Economic Policy, 15(30), pp. 7-46.

[24] Schnabl, G. (2009). Exchange Rate Volatility and Growth in Emerging Europe and East Asia. Open Economic Review, 20: pp. 565 - 587.

[25] Tenreyro, Silvana. (2004). On the Trade Impact of Nominal Exchange Rate Volatility. Research Department Working Paper No. 03-2, Federal Reserve Bank of Boston.

[26] Thorbecke, W. (2008). The effect of exchange rate volatility on fragmentation in East Asia: Evidence from the electronics industry. Journal of the Japanese and International Economies 22(4) pp. 535-44.

[27] Tinbergen, Jan. (1962). Shaping the World Economy: Suggestions for an International Economic Policy. New York: Twentieth Century Fund.

[28] Verbeek, M. (2004). A Guide to Modern Econometrics. 2nd Edition. John Wiley and Sons, Ltd.

[29] Wei, S.J. (1999). Currency hedging and goods trade. European Economic Review 43, pp. 1371-1394. 


\section{Appendix}

\section{Table A1: Description of Variables and Data Sources}

\begin{tabular}{|c|c|c|}
\hline Variable & Description (Figures in US\$ unless otherwise stated) & Source \\
\hline TDC & Total Trade (Exports + Imports) with COMESA Countries & $\begin{array}{c}\text { COMSTAT } \\
\text { (COMESA Data Base) }\end{array}$ \\
\hline ExC & Total exports with COMESA Countries & $\begin{array}{c}\text { COMSTAT } \\
\text { (COMESA Data Base) }\end{array}$ \\
\hline IMC & Imports from COMESA & $\begin{array}{c}\text { COMSTAT } \\
\text { (COMESA Data Base) }\end{array}$ \\
\hline TDW & Total trade of country I with the world & $\begin{array}{c}\text { COMSTAT } \\
\text { (COMESA Data Base) }\end{array}$ \\
\hline EXW & Total exports of country I with the world & $\begin{array}{c}\text { COMSTAT } \\
\text { (COMESA Data Base) }\end{array}$ \\
\hline IMW & Imports of country I from WORLD & $\begin{array}{c}\text { COMSTAT } \\
\text { (COMESA Data Base) }\end{array}$ \\
\hline $\begin{array}{l}\text { REER } \\
(2010=100)\end{array}$ & $\begin{array}{l}\text { Real effective exchange rate is the nominal effective exchange rate (a } \\
\text { measure of the value of a currency against a weighted average of several } \\
\text { foreign currencies) divided by a price deflator or index of costs. }\end{array}$ & $\begin{array}{l}\text { International Financial } \\
\text { Statistics (IFS) }\end{array}$ \\
\hline Px & $\begin{array}{l}\text { Is the relative price of exports between the two countries proxied by the } \\
\text { Real Effective Exchange Rate (REER) }\end{array}$ & $\begin{array}{l}\text { International Financial } \\
\text { Statistics (IFS) }\end{array}$ \\
\hline $\begin{array}{l}\text { GDP } \\
\text { (constant } \\
2010 \text { US\$) }\end{array}$ & $\begin{array}{l}\text { GDP at purchaser's prices is the sum of gross value added by all resident } \\
\text { producers in the economy plus any product taxes and minus any } \\
\text { subsidies not included in the value of the products. It is calculated } \\
\text { without making deductions for depreciation of fabricated assets or for } \\
\text { depletion and degradation of natural resources. Data are in constant } \\
2010 \text { U.S. dollars. Dollar figures for GDP are converted from domestic } \\
\text { currencies using } 2010 \text { official exchange rates. For a few countries } \\
\text { where the official exchange rate does not reflect the rate effectively } \\
\text { applied to actual foreign exchange transactions, an alternative } \\
\text { conversion factor is used. }\end{array}$ & $\begin{array}{l}\text { World Bank national } \\
\text { accounts data, and OECD } \\
\text { National Accounts data files. }\end{array}$ \\
\hline pop & $\begin{array}{l}\text { Total population is based on the de facto definition of population, which } \\
\text { counts all residents regardless of legal status or citizenship. The values } \\
\text { shown are midyear estimates. }\end{array}$ & $\begin{array}{l}\text { World Development } \\
\text { Indicators }\end{array}$ \\
\hline NBR & Dummy for sharing a border & Author Computation \\
\hline LG & Dummy for sharing an Official Language & Author Compilation \\
\hline DIS & Distance in KM by air between the capitals & Travel Distance Calculator \\
\hline $\mathrm{CV}$ & Conditional Variance & $\begin{array}{c}\text { This is generate from } \\
\text { GARCH }(1,1) \text { estaimation }\end{array}$ \\
\hline Countries & $\begin{array}{l}\text { Burundi (BI), Comoros (KM), Congo DR (CD), Djibouti (DJ), Egypt } \\
\text { (EG), Eritrea (ER), Ethiopia (ET), Kenya (KE), Libya (LY), } \\
\text { Madagascar (MG), Malawi (MW), Mauritius (MU), Rwanda (RW), } \\
\text { Seychelles (SC), Sudan (SD), Swaziland (SZ), Uganda (UG), Zambia } \\
\text { (ZM) and Zimbabwe (ZW). }\end{array}$ & COMESA Member Countries \\
\hline
\end{tabular}

